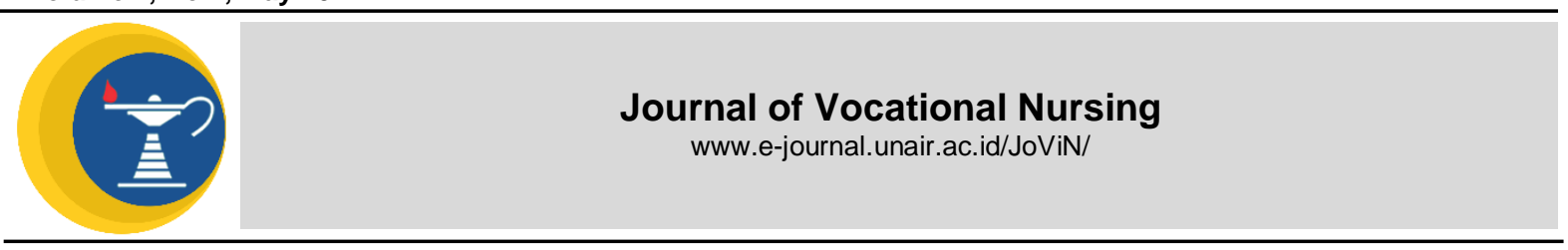

\title{
THE RELATIONSHIP BETWEEN BEHAVIOR OF USING REPEATED COOKING OILS AND RECURRENCE OF HYPERTENSION
}

\author{
Mella Novika Sari and Dhian Luluh Rohmawati
}

Research Report

Akademi Keperawatan Pemerintah Kabupaten Ngawi

\section{A B S TRACT}

Introduction: Hypertension is an abnormal increase in systolic blood pressure of more than $140 \mathrm{mmHg}$ and diastolic more than $90 \mathrm{mmHg}$. Hypertension cannot be cured as a whole, therefore hypertension can recur. One of the factors in the occurrence of recurrence is the use of repeated cooking oil. Repeated cooking oil is cooking oil that has been used repeatedly more than once. The aim of this research to determine the relationship between the behavior of repeated use of cooking oil and the recurrence of hypertension. Methods: The design repeated is correlation with cross sectional approach. The sampling technique was carried out by purposive sampling with a sample size of 82 respondents. Collecting data using a questionnaire instrument with data processing using the T-score and Chi Square statistical test. The results of this study found that 47 respondents $(57.3 \%)$ behaved using repeated cooking oil and found that 42 respondents (51.2\%) experienced frequent recurrence of hypertension. Result: The results showed a significant relationship between the behavior of using repeated cooking oil and the recurrence rate of hypertension $(p=0.002)$. Conclusion: Further researchers need to be investigated related to nutritional pattern factors, smoking history, stress and others. In addition, it can be researched regarding the knowledge of the dangers of using repeated cooking oil for health.

\section{ARTICLE INFO}

Received February 16, 2021

Accepted May 30, 2021

Online May 31, 2021

*Correspondence:

Dhian Luluh Rohmawati

*Email:

dhian.luluh@gmail.com

Keywords:

Repeated cooking oils

Hypertension recurrence

\section{INTRODUCTION}

Indonesian people generally use deep frying so that there will be repeatedly cooking oil. Repeated cooking oil is usually reused for frying food (Warouw, 2012). This is triggered by the high price of oil for some people and the lack of public knowledge about the dangers that can be caused by using repeated cooking oil, one of which is hypertension (Amalia and Johan, 2010). Indonesia, which is one of the developing countries, has quite complex health problems, ranging from infectious to non-communicable diseases (Sumarna et al, 2019). One of these noncommunicable diseases is hypertension (Simamora et al, 2019). Hypertension is an increase in systolic blood pressure equal to or higher than $140 \mathrm{mmHg}$ and or diastolic pressure equal to or higher $90 \mathrm{mmHg}$ (Saputra, Muhith and Fardiansyah, 2017). Hypertension couldn't be cured as a whole, therefore hypertension could recurrence (Widyastuti, 2015).
According data from the World Health Organization (WHO), the number of hypertension sufferers increased from 594 million people in 1975 to 1.13 billion in 2015 . Prevalence of hypertension in the world shows that Africa has the highest prevalence, namely $27 \%$ or about 305.1 million people, while America has a low prevalence, namely $18 \%$ or around 203.4 million people (WHO, 2019). Based on the 2018 Riskesdas data, the prevalence of hypertension in Indonesia is 658,201 people. The highest incidence of hypertension is in West Java Province with 121,153 people, while East Java is in second place with 105,380 people (Kemenkes RI, 2018). Data from Ngawi District Health Office in 2019 states that the number of hypertension sufferers served at the Puskesmas in 2019 was 123,155 cases. Ngawi District was in third place with 9,536 cases (Dinkes Kabupaten Ngawi, 2019). 
The recurrence of hypertension is influenced by many factors including obesity, smoking habits, stress, hypertensive diet, diet, use of excess cooking oil or repeated cooking oil (Putri, 2014). One of the factors that influence the recurrence of hypertension is the use of repeated cooking oil, repeated consumption of repeated cooking oil will cause a progressive and slow accumulation of fat. Plaque can cause atherosclerosis which will reduce or block blood flow to the tissues. The accumulation of arterial muscle cells causes a loss of elasticity and constriction of blood vessels which causes hypertension (Putri, 2017; Amalia and Johan, 2010).

Seeing the phenomenon in society, it is necessary to provide promotional knowledge by providing information to the public about the behavior of using disposable cooking oil and limiting the oil needed when frying (Arifin, 2017). Preventive action can be done by making changes in food processing and doing diet. Curative action can be handled pharmacologically with antihypertensive drugs (Soleha, 2019). Rehabilitative measures can be carried out by controlling blood pressure (Widyastuti, 2015).

Based on the results of a simple field study through interviews with 5 people with hypertension in the District of Ngawi Kota, it was found that 1 respondent did not use repeated cooking oil and 4 used repeated cooking oil. Respondents who did not use repeated cooking oil experienced recurrence of hypertension $<5$ times in one year. Respondents who used repeated cooking oil experienced recurrence $<5$ times in one year as many as 1 respondent and $>5$ times in one year as many as 3 respondents. Based on the description above and previous research on the behavior of using repeated cooking oil with the incidence of hypertension, there is a study which states that there is a relationship between the behavior of using repeated cooking oil and the incidence of hypertension. Based on the above background, the researchers are interested in conducting more in-depth research related to the relationship between the behavior of using repeated cooking oil and the recurrence rate of hypertension. The purpose of this study was to determine the relationship between the behavior of using repeated cooking oil and the recurrence rate of hypertension.

\section{MATERIALS AND METHODS}

This research was an correlation research with a cross sectional approach. The population in this research was all hypertension sufferers in Ngawi City District. The sampling technique was carried out by purposive sampling with a sample size of 82 respondents. The inclusion criteria of this study is hypertension sufferers aged 45 years and over in Ngawi District, patient with hypertension at least one year, willing to be a respondent, respondents can read and write. Research instrument used to measure the behavior of using repeated cooking oil using a questionnaire was sourced from research conducted by Arifin (2017). The recurrence rate of hypertension using a questionnaire was sourced from the research of Widyastuti (2015). The questionnaire contains questions about recurrence of hypertension for one year, it is stated sometimes if $<5$ times in one year and often if $>5$ times in one year. All data were entered into SPSS $21^{\text {th }}$ version. Collecting data using a questionnaire instrument with data processing using the T-score and Chi Square statistical test.

\section{RESULTS}

Table 1 Relationship between Repeated Cooking Oil Behavior and Hypertension Recurrence Hypertension $(\mathrm{n}=82)$.

\begin{tabular}{|c|c|c|c|c|c|c|c|c|c|c|}
\hline \multirow[t]{3}{*}{$\begin{array}{l}\text { Behavior } \\
\text { Cooking Oil }\end{array}$} & \multirow[t]{3}{*}{ Using } & \multirow[t]{3}{*}{ Repeated } & \multicolumn{4}{|c|}{$\begin{array}{l}\text { Recurrence of } \\
\text { Hypertension }\end{array}$} & \multirow{2}{*}{\multicolumn{2}{|c|}{ Total }} & \multirow[t]{3}{*}{ OR } & \multirow[t]{3}{*}{$P$ Value } \\
\hline & & & \multicolumn{2}{|c|}{$<5 x /$ year } & \multicolumn{2}{|c|}{$>5 x /$ year } & & & & \\
\hline & & & $\mathrm{n}$ & $\%$ & $\mathrm{n}$ & $\%$ & $\mathrm{n}$ & $\%$ & & \\
\hline \multicolumn{3}{|c|}{ Using Repeated Cooking Oil } & 16 & 19.5 & 31 & 37.8 & 47 & 57.3 & \multirow[t]{2}{*}{0.237} & \multirow[t]{2}{*}{0.002} \\
\hline \multicolumn{3}{|c|}{ Not using Repeated Cooking Oil } & 24 & 29.3 & 11 & 13.4 & 35 & 42.7 & & \\
\hline
\end{tabular}

It was found that some of the hypertensive patients behaved using repeated cooking oil by 47 respondents $(57.3 \%)$. Patients with hypertension who used repeated cooking oil experienced a recurrence rate of $>5$ times in one year, namely 42 respondents (51.2\%). Meanwhile, patients who did 
not use repeated cooking oil experienced a recurrence rate of hypertension $5 x$ in one year (often) less, namely 11 respondents (13.4\%). In this test, a statistical test was carried out with Chi Square, with a degree of safety of $95 \%$. Stated significant if the $P$ value $\leq 0.05$ and not significant if the $P$ value $>0.05$. Based on the results of tabulation and calculation of Chi Square with SPSS Windows 21, the value of $P$ value $=0.002$ shows that $P$ value $<0.05$, in other words, there is a relationship between the behavior of using repeated cooking oil and the rate of recurrence of hypertension (frequent). While the OR value is 0.237 , so the strength of the relationship is rather low.

\section{DISCUSSION \\ Behavior Description Using Repeated Cooking Oil}

Based on the results of the study, it is known that hypertensive patients in Ngawi Kota have a higher behavior of using repeated cooking oil as many as 47 respondents $(57.3 \%)$. This is in line with Arifin's research (2017) which states that the behavior of using repeated cooking oil is higher than those who do not use repeated cooking oil. There are factors that become the reasons for the first habit of using repeated cooking oil, there is often an opinion that using repeated cooking oil can add a savory taste to cooking and the second is due to economic factors (Nadirawati and Muthmainnah, 2010).

Repeated cooking oil is cooking oil that has been used for frying which is used repeatedly, more than once, the oil will be damaged (Saputra et al, 2017). Oil that has been damaged experiences changes in taste, aroma, texture, color, rancidity and oxidation from cooking at high temperatures (Denni, 2019). The reason for the high price of cooking oil for some people and the lack of knowledge makes people often use repeated cooking oil (Amalia and Johan, 2010). The theory of Priani and Lukmayani (2010) also states that the use of repeated cooking oil is due to the high price of palm oil which is accompanied by an economic crisis. People tend to reuse repeated oil to process their daily food for savings without considering health hazards.

Likewise, from the research results, it was found that respondents who used repeated cooking oil found that 26 respondents (55.3\%) had self-employed jobs with uncertain salaries. The income of family members will of course affect the amount and pattern of consumption of an item, this will affect the use of cooking oil repeatedly for reasons of economizing. In accordance with the theory of Putri (2014), the economic background in the family in working to earn a living can affect the limitations of respondents in the economy so that it makes it difficult to meet their daily needs.

\section{Overview of Hypertension Recurrence Rate}

Based on the results of research on the distribution of respondents based on the recurrence rate of hypertension, it is known that the respondents experienced recurrence of more than 5 times in one year as many as 42 respondents (51.2\%). Based on research conducted hypertension recurrence occurred more frequently in female sex, namely 28 respondents $(59.6 \%)$. This is in accordance with a study conducted by Putri (2014) which states that hypertension recurrence occurs in women after over 50 years of age.

Recurrence of hypertension is a condition where the symptoms of the disease appear the same as before in a period of one year (Muawanah, 2012; Putri, 2014). Several factors cause recurrence of hypertension such as obesity, smoking habits, stress, hypertensive diet, diet, not taking regular medication, use of repeated cooking oil (Putri, 2014; Widyastuti, 2015). According to the theory of Muhartono et al., (2018), recurrence of hypertension is due to consumption of repeated cooking oil which contains many free radicals due to lipid peroxidation which can damage blood vessels, heart, liver, and kidneys due to fat accumulation (atherosclerosis). The use of repeated cooking oil can also cause histological abnormalities and changes in genetic material due to free radicals produced during the frying process which can damage lipid membranes, then trigger oxidative stress. This will induce cell injury or injury that causes damage to the cell structure with the occurrence of necrosis and infiltration of inflammatory cells in target organs, such as the heart and liver. The use of repeated cooking oil can cause plaque in blood vessels and cause atherosclerosis which can lead to recurrence of hypertension (Muhartono et al, 2018; Putri, 2017; Amalia and Johan, 2010).

\section{The Relationship between the Behavior of Using Repeated Cooking Oil and the Recurrence Rate of Hypertension}

Based on the results of the research on the relationship between the behavior of using repeated cooking oil and the recurrence rate of hypertension in the District of Ngawi City, it was found that most of the respondents who used repeated cooking oil experienced a recurrence rate that was more frequent. In contrast, respondents who did not use used cooking oil experienced occasional recurrence. In this study, the obtained $P$ value $=0.002$ 
indicates $P$ value $<0.05$, in other words there is a relationship between the behavior of using used cooking oil and the rate of recurrence of hypertension (frequent). While the OR value is 0.237 , so the strength of the relationship is rather low. This is in line with research conducted by Arifin (2017) which states that there is a significant relationship between the use of used cooking oil and the incidence of hypertension with a $P$ value $=0.000$.

The recurrence of hypertension caused by used cooking oil stated by Putri (2014), recurrence of hypertension can occur because used cooking oil contains many free radicals due to lipid peroxides. Exposure to free radicals and free fatty acids produced from used cooking oil will enter the body and cause oxidative stress. If free radicals enter continuously, it will cause the formation of lipid peroxide which makes free radicals more toxic and very dangerous and very easily damages cells in the body. Cells that are often attacked are endothelial cells in blood vessels. If endothelial cells are attacked, blood vessel endothelial dysfunction will occur, the dysfunction will cause damage to blood vessels and the blood vessel endothelium will experience impaired production of nitric oxide which of course affects the balance between prostacyclin, which decreases and thromboxane has increased. When this happens the blood vessels constrict and cause platelet / platelet aggregation. When endothelial dysfunction occurs due to oxidative stress, there will be an increase in the production of macrophage cells and there will be increased permeability and adhesiveness of blood vessels to lipoproteins, leukocytes, platelets and other plasma contents. Therefore, the very high fatty acid content in used cooking oil makes it easy to attach to the walls of blood vessels, which will accumulate and form atherosclerotic plaque. Atherosclerotic plaques are formed due to the accumulation of fat, macrophages, platelets or platelets in the tunica intima and tunica media which are the walls or lining of blood vessels. Therefore, the walls of the blood vessels are thickened so that the diameter of the lumen will be smaller and narrower, leading to atherosclerosis.

Atherosclerosis will block blood flow to the body's tissues and reduce the amount of blood flow and cause a loss of elasticity and constriction of blood vessels so that the regulation of blood pressure is reduced which triggers hypertension. Consumption of used cooking oil in the daily cooking of hypertensive patients causes atherosclerosis in blood vessels. This further confirms the recurrence of relapses during the one year period after the first attack. This relationship is related to the use of used cooking oil which shows that in cooking with used cooking oil it will increase cholesterol levels in the blood so that it will increase the risk of atherosclerosis which will increase blood pressure and the risk of hypertension recurrence (Muhartono et al, 2018; Putri, 2017; Amalia and Johan, 2010).

\section{CONCLUSION}

Based on research on the relationship between the behavior of using repeated cooking oil with the recurrence rate of hypertension in Ngawi Regency, it was found that most of the respondents who used repeated cooking oil experienced a recurrence rate that was more frequent. Meanwhile, respondents who did not use used cooking oil experienced a relapse. In this study, the value of $P=0.002$ which indicates a $P$ value $<0.05$, in other words there is a relationship between the behavior of using used cooking oil with the recurrence rate of hypertension (frequent). While the OR value is 0.237 , so the strength of the relationship is rather low.

From these studies it can be concluded that the repeated use of cooking oil can cause hypertension so that the results of this study are expected to increase public knowledge to better maintain health by not consuming repeated cooking oil for daily activities continuously.

\section{REFERENCES}

Amalia, F., Retnaningsih, and Johan, I. R. (2010). Perilaku Penggunaan Minyak Gireng serta Pengaruhnya Terhadap Keikutsertaan Program Pengumpulan Minyak Jelantah di Kota Bogor. Jurnal Ilmu Keluarga \& Komunitas, 3(2), 184189.

Arifin, K. (2017). Hubungan Perilaku Menggunakan Minyak Goreng Bekas (Jelantah) dengan Kejadian Penyakit Hipertensi pada Ibu Rumah Tangga. Retrieved October 2, 2019, from http://eprints.umpo.ac.id/id/eprint/3408

Denni, N. P. R. (2019). Mutu Minyak Goreng pada Pedagang Gorengan di Kecamatan Denpasar Utara. Karya Tulis Ilmiah. Poltekkes Kemenkes Denpasar.

Dinas Kesehatan Kabupaten Ngawi. 2019. Data Penyakit Tidak Menular Tahun 2019. Ngawi : Bidang Pencegahan dan Pengendalian Penyakit Dinas Kesehatan Kabupaten Ngawi

Kementrian Kesehatan Republik Indonesia. 2019. Laporan Nasional RISKESDAS 2018. Jakarta: Lembaga Penerbit Badan Penelitian dan Pengembangan 
Keehatan (LPB).

Muawanah. (2012). Hubungan Tingkat Pengetahuan Tentang Manajemen Stres Terhadap Tingkat Kekambuhan pada Penderita Hipertensi di Panti Wreda Dharma Bakti Surakarta. Skripsi.Universitas Muhammadiyah Surakarta. Fakultas IImu Kesehatan

Muhartono (2018). Minyak Jelantah Menyebabkan Kerusakan pada Arteri Koronaria, Miokardium, dan Hepar Tikus Putih (Rattus Norvegicus) Jantan Galur Sprague Dawley., Jk Unila, 2(2), 129-135.

Nadirawati and Muthmainnah, N. N. (2010). Pengetahuan lbu Rumah Tangga Tentang Kolesterol dan Penggunaan Minyak Jelantah (Waste Cooking Oil) di Desa Neglasari Kecamatan Bojong Picung Cianjur, The Soedirman Journal of Nursing, 5(2), 58-65.

Priani, S. E. and Lukmayani, Y. (2010). Pembuatan Sabun Transparan Berbahan Dasar Minyak Jelantah Serta Hasil Uji Iritasinya pada Kelinci, Prosiding SNAPP: Sains dan Teknologi, 1(1), 31-48.

Putri, F. V. (2017). Hubungan Antara Asupan Lemak Jenuh, Asupan Lemak Tidak Jenuh, dan Frekuensi Konseling dengan Status Hipertensi di Puskesmas Sentolo I Kabupaten Kulonprogo Tahun 2017. skripsi. Politeknik Kesehatan Kemenkes Yogyakarta.

Saputra, M. H., Muhith, A. dan Fardiansyah, A. (2017). Analisis Sistem Informasi Faktor Resiko Hipertensi Berbasis Posbindu di Dinas Kesehatan Kabupaten Sidoarjo. Prosiding Seminar Nasional.

Simamora, L., Sembiring, N. P. dan Simbolon, M. (2019). Pengaruh Riwayat Keluarga, Obesitas dan Stress Psikosial Terhadap Kejadian Hipertensi pada lbu Pasangan Usia Subur di Wilayah Kerja Puskesmas Simalingkar Program Studi Profesi Kebidanan, Stikes Mitra Husada Medan Email : Lasriasimamora@Gmail.Com

Program, Jurnal Mutiara Ners, 2(1), 188-194.

Soleha, U. (2019). Analisis Life Style Berdasarkan Faktor Karakteristik Penderita Hipertensi di RW. 09 Desa Sruni Gedangan Sidoarjo Jawa Timur Indonesia, Journal Health Of Science, 12, 93-101.

Sumarna, U., Rosidin, U. dan Nugraha, B. A.
(2019). Hubungan Kualitas Tidur dengan Tekanan Darah pada Pasien Prehipertensi Puskesmas Tarogong Garut, Jurnal Keperawatan BSI, 7(1), 1-3. DOI: https://doi.org/10.31311/jk.v7i1.3929

Warouw, J. A. M. (2012). Hubungan Antara Pengetahuan dan Sikap dengan Tindakan Penggunaan Minyak Jelantah pada Pelaku Usaha Rumah Makan di Kelurahan Bahu Kecamatan Malalayang Kota Manado, Retrieved October 5, 2019, from https://fkm.unsrat.ac.id/wpcontent/uploads/2012/10/FeratImbiri.pdf

WHO (2019) 'Hypertension'. Available At: Https:/Www.Who.Int/News-

Room/Fact-

Sheets/Detail/Hypertension.

Widyastuti, Y. (2015). Hubungan Antara Kualitas Tidur Lansia dengan Tingkat Kekambuhan pada Pasien Hipertensi di Klinik Dhanang Husada Sukoharjo. Skripsi. Stikes Kusuma Husada Surakarta. 